\title{
Judges, Masters, Diviners: Slaves' Experience of Criminal Justice in Colonial Suriname-Corrigendum
}

\section{NATALIE ZEMON DAVIS}

doi: $10.1017 /$ S0738248011000496, Published by Cambridge University Press, 28 October 2011

In footnotes 75 and 90, on pages 957 and 965 respectively of Law and History Review volume 29 number 4 (November 2011), the title of Richard Price's Alabi's World is misspelled as Alibi's World. The footnotes, with the correct spelling, are as follows:

75. Schumann, SD Wörter-buch, 76; Riemer, "Wörterbuch," 301-2; Riemer, "Mitteilungen," in Staehelin, Mission, vol. 3, part 2, 265-66; and Price, Alabi's World, 373-74.

90. Riemer, "Mitteilungen," in Staehelin, Mission, vol. 3, part 2, 267-68 and Price, Alabi's World, 374-75. In addition, Schumann includes the word "asempreh" in his Saramaccan-German dictionary and defines it as "a kind of torture: a cord with a knot is bound around the head and tightened very firmly in order to compel a malefactor to confession" (SD Wörter-buch, 49). 